\title{
Bats (Mammalia, Chiroptera) of an urban park in the metropolitan area of Rio de Janeiro, southeastern Brazil
}

\author{
Carlos E.L. Esbérard ${ }^{1}$, Júlia L. Luz², Luciana M. Costa ${ }^{1,3}$ \& Helena G. Bergallo ${ }^{3}$
}

\author{
1. Laboratório de Diversidade de Morcegos, Instituto de Biologia, Universidade Federal Rural do Rio de Janeiro, km 47 da antiga estrada Rio - São Paulo, Caixa Postal 74507, 23890-000, \\ Seropédica, RJ, Brazil. (cesberard@superig.com.br) \\ 2. Instituto Federal do Sudeste de Minas Gerais, Campus Juiz de Fora, Núcleo de Biologia, Rua Bernardo Mascarenhas, 1283, Bairro Fábrica, 36080-001, Juiz de Fora, MG, Brazil. \\ (julialinsluz@yahoo.com.br) \\ 3. Laboratório de Ecologia de Mamíferos, Departamento de Ecologia, Instituto de Biologia, Universidade do Estado do Rio de Janeiro, Rua São Francisco Xavier, 524, 20550-013, \\ Rio de Janeiro, RJ, Brazil. (costalucianam@gmail.com; nena.bergallo@gmail.com)
}

\begin{abstract}
Some bat species are able to adapt to urban areas, where they find food and roosts. Despite the high number of parks in Brazilian cities, they did not yet raise the interest of most zoologists, except for some surveys of birds and butterflies. The objectives of the present study were: (i) to inventory the bat species of Quinta da Boa Vista (QBV), a large ( 25 ha) urban park centrally located in densely populated Rio de Janeiro, which is Brazil's second largest metropolis; (ii) to compare the species richness observed in roosts with the richness recorded through mist netting in flight routes and near fruiting fig trees; and (iii) to analyze recaptures of bats marked in this park and recaptured in other sites and vice-versa. Sampling totaled 104 sampling nights resulting in 3,256 captures (including 133 recaptures) between April 1989 and December 2004. We also sampled roosts and received some specimens from park visitors and city workers. We documented 21 bat species, predominantly large frugivores. The number of expected species for this park was $24.0 \pm 4.6$, and the total sampled represented $87.5 \%$ of the expected. The recapture of bats marked in surrounding forest fragments and in QBV shows the importance of urban parks for the maintenance of bat diversity. Inspection of roosts produced two species that had not been captured with other methods. Sampling near fruiting fig trees did not differ in terms of richness from sampling carried out far from these trees or during their non-fruiting periods.
\end{abstract}

KEYWORDS. Diversity, long-term, samples, urban area.

RESUMO. Morcegos (Chiroptera) de um parque urbano na região metropolitana do Rio de Janeiro, sudeste do Brasil. Algumas espécies de morcegos são capazes de se adaptar às áreas urbanas, onde encontram alimento e abrigo. Apesar do elevado número de parques nas cidades brasileiras estas ainda não despertaram o interesse dos zoólogos, exceção feita a inventários de aves e borboletas. Os objetivos do presente estudo foram: (i) inventariar as espécies de morcegos da Quinta da Boa Vista (QBV), um grande ( 25 ha) parque urbano centralmente localizado na povoada cidade do Rio de Janeiro, a segunda maior metrópole do Brasil; (ii) comparar a riqueza de espécies observadas em refúgios com a riqueza registrada através de redes de neblina abertas em rotas de voo e perto de figueiras em frutificação; e (iii) analisar as recapturas de morcegos marcados neste parque e recapturados em outras localidades, e vice-versa. A amostragem totalizou 104 noites, resultando em 3.256 capturas (incluindo 133 recapturas) entre abril de 1989 e dezembro de 2004. Nós também amostramos abrigos e recebemos alguns exemplares de visitantes do parque e dos cidadãos. No total, nós documentamos 21 espécies de morcegos, com a predominância de grandes frugívoros. O número de espécies esperadas para este parque foi de $24,0 \pm 4,6$, e o total amostrado representado foi de $87,5 \%$ do esperado. As recapturas de morcegos marcados em torno dos fragmentos florestais e em QBV mostram a importância de parques urbanos para a manutenção da diversidade de morcegos. As buscas e amostragens em abrigos resultaram em duas espécies que não tinham sido capturadas com outros métodos. As amostragens perto de figueiras em frutificação não diferiram em termos de riqueza em relação às amostragens realizadas longe destas árvores, ou durante os seus períodos de não frutificação.

PALAVRAS-CHAVE. Diversidade, longo prazo, amostragens, área urbana.

The Brazilian bat fauna of urban areas has received little attention, though it presents an opportunity to investigate which species can adapt to the increasing human alterations in the environment (Lima, 2008). Public awareness of urban forestry (SANTOS et al., 2009) and maintenance of green areas, such as urban parks with trees, is recent in Brazil (e.g., Gomes \& SoARes, 2003; SANTOS et al., 2009). In these areas live both species that survived human alterations and those that benefited from them (e.g., Bredt et al., 1996; KuRTA \& Teramino, 1992; Ávila-Flores \& Fenton, 2005).

Some bat species are able to adapt to urban areas, where they find food and roosts (e.g., CôRTES et al., 1994; Bredt et al., 1996; SAZima et al., 1994; Fenton, 1997; EsbérARD et al., 1999; ZÓRTEA \& AgUiAR, 2001; Lima, 2008; GAZARINI \& PEDRO, 2013). In these areas they can reach high density, as a result of the absence of predators and potential competitors, and of the abundance of resources. Urban forestry, in spite of giving preference to resistant, fast-growing plant species regardless of origin (MiLANo \& DALCIN, 2000; SANTOS et al., 2009), produces areas that are frequently used by urban bats.

Some insectivorous bats can easily obtain their prey in urban areas, which can be attracted by street lighting (Bredt \& Uieda, 1996; Silva et al., 1996). However, the diversity of insectivorous bats in urban areas is lower than in neighboring natural areas (KURTA \& TERAmino, 1992). Even hematophagous bat species can be found in urban areas, where they attack pets and humans (UIEDA, 1995; EsBÉRARD, 1999; Carneiro et al., 2005; Ferraz et al., 2007). Within urban environments, bat density and diversity can vary due to several factors, such as roost availability, presence and distance among trees, and water availability (CôRTES et al., 1994; Bredt et al., 1996; Fenton, 1997; SAzima et 
al., 1994; Esbérard et al., 1999; Zórtea \& Aguiar, 2001; Lima, 2008; OpREA et al., 2009).

Urban parks differ from forest fragments, because they have lower tree density, lower plant diversity, and higher predominance of exotic tree species. Because these parks are urban areas and not true forest remnants, their bat fauna is expected to comprise only species that are highly adapted to urban environments, and lack species that depend on a minimum forest area to survive (ÁvilLAFlores \& Fenton, 2005; Oprea et al., 2009). Despite the high number of parks in Brazilian cities, they did not yet raise the interest of most zoologists, except for some surveys of birds and butterflies (Matarazzo-NEUBERgER, 1995; VillanueVa \& Silva, 1996; Fortunato \& RUSZCZyK, 1997; RUSZCZYK et al., 1987).

Lima (2008) compared the bat fauna of several Brazilian cities, using lists available in papers and conference abstracts. However, several localities included in this analysis are forest fragments that were preserved and are currently used by the public, as in Rio de Janeiro, where eight parks have been sampled, which are actually forest remnants and not urban parks (see EsBÉRARD, 2003a). Lists of bat species of Brazilian metropolitan areas are available for Brasília (BREDT \& UiedA, 1996), Belo Horizonte (KNEGT et al., 2005), Juiz de Fora (BARros et al., 2006), São Paulo (Silva et al., 1996; GaZARini \& Pedro, 2013), and Londrina (REIs et al., 2002). However, these lists were based mainly on donated animals (SiLVA et al., 1996) or on few sampling nights in most localities (BREDT \& UIEDA, 1996; REIS et al., 2002; KNeGT et al., 2005; BARRos et al., 2006). There are no studies based on a large sample taken at a single sampling site in an urban area in Brazil. For the city of Rio de Janeiro there is no published bat inventory, though it is known that at least 27 species recorded for the state use roof lining and other human structures as day or night roosts (EsbérARD et al., 1999).

A bat inventory made in an urban park within a Brazilian metropolis would be something new and it could help advance the knowledge of species that are well adapted to urbanization. Therefore, the objective of the present study was to inventory the bat species of Quinta da Boa Vista, a large urban park with large amount of trees in the second largest Brazilian metropolis. We aimed also at comparing the species richness observed in roosts with the richness recorded through mist netting in flight routes and near fruiting fig trees, and at analyzing recaptures of bats marked in this park and recaptured in other sites and vice-versa.

\section{MATERIAL AND METHODS}

The metropolis of Rio de Janeiro (6.32 million inhabitants) is occupied mainly by residences, with smallscale agriculture and cattle raising located mainly in the periphery. The city occupies an area of $1,200 \mathrm{~km}^{2}$, with an average density of 5,265 inhabitants $/ \mathrm{km}^{2}$ (IBGE, 2010). Forest remnants, which correspond to $18 \%$ of the city's

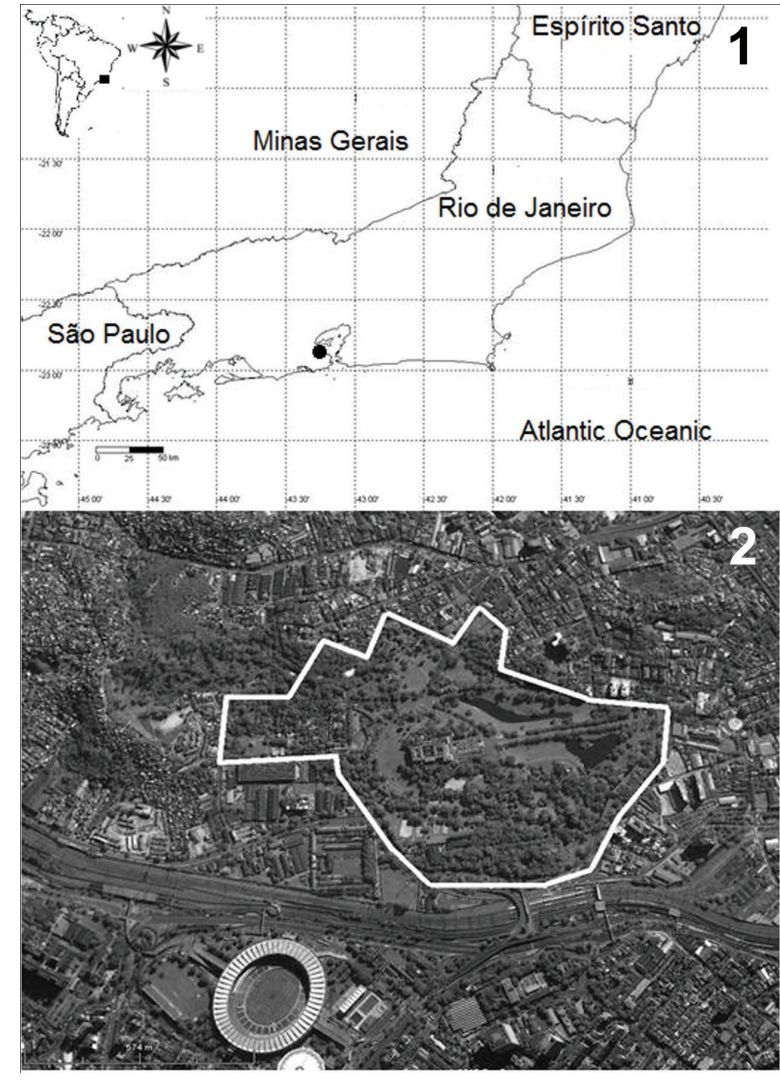

Figs 1, 2: 1, South America and the state of Rio de Janeiro, with Quinta da Boa Vista marked in black; 2, Ortophoto of 2004, with Quinta da Boa Vista (sampled from 1989 to 2004) marked in white, (provided by Prefeitura da Cidade do Rio de Janeiro, number 587).

area (Fundação SOS Mata Atlântica, 2002), are restricted to elevations varying from $100 \mathrm{~m}$ to over $400 \mathrm{~m}$ a.s.l., with a predominance of second-growth Atlantic Forest (BERGALlo et al., 2009). The predominant climate is humid tropical, with minimum temperatures of $17{ }^{\circ} \mathrm{C}$ and maximum of $36{ }^{\circ} \mathrm{C}$, average relative humidity around $80 \%$, average annual rainfall of $1,107 \mathrm{~mm}$, and 124 rainy days per year (IPLANRIO, 1992).

Quinta da Boa Vista (hereafter QBV) is an urban park of 25 ha, located in a central area of Rio de Janeiro (Figs 1,2), in an industrial area with population density of 839.0 inhabitants $/ \mathrm{km}^{2}$, where the Museu Nacional and the Zoological Gardens are located. It is destined to public recreation and receives a total of 100,000 visitors every weekend (IPLANRIO, 1992).

QBV has low tree density $\left(0.04\right.$ trees $\left./ \mathrm{km}^{2}\right)$, had its landscape architecture designed by Auguste Glaziou in 1878 , and is protected by the Institute of National Heritage (Instituto do Patrimônio Histórico Nacional, PCRJ, 1998). Its predominant plant species are fruiting trees, such as Lecythis pisonis (Lecythidaceae), Licania tomentosa (Chrysobalanaceae), Mangifera indica (Anacardiaceae), Spondias dulci (Anacardiaceae), Terminalia catappa (Combretaceae), Ficus spp. (Moraceae) (several native species, but mainly the exotic species Ficus religiosa, Ficus microcarpus, Ficus tomentella, and Ficus clusiaefolia), Chrysophyllum caimito (Sapotaceae), Achras zapota 
(Sapotaceae), Artocarpus integrifolia (Moraceae), and Syagarus romanzoffiana (Palmae) (PCRJ, 1998). Most trees are older than 115 years. The area has also artificial lakes and an artificial cave. It is mainly characterized by vast lawns and an alley with cream nuts (Lecythis pisonis), locally known as "sapucaias", which delimit the entrance of the Museu Nacional. Part of the area was used for the City Garden, currently part of the Museu Nacional (PCRJ, 1998).

Sampling was carried out between April 1989 and December 2004, without a temporal criterion and at all moon phases (EsBÉRARD, 2007). We carried out 104 sampling nights ( 0.60 sampling nights/month), summing up $793 \mathrm{~h}$ (average of $7.6 \mathrm{~h}$ per sampling night) and 4,050 $\mathrm{m}$ of mist nets $\left(10,125 \mathrm{~m}^{2} . \mathrm{h}\right)$. At each night, from five to 13 nets were opened $(7 \times 2.5 \mathrm{~m}$, mesh $20 \mathrm{~mm}$, average of $97.5 \mathrm{~m}^{2}$ per night) from before sunset to 24:00 (from 1989 to 1993) or until sunrise (from 1994 to 2004). Nets were set up in eight different sites of the park: four in the zoo and four in other areas. In the four sites of the zoo, nets were opened in the visitation alleys or inside animal enclosures without bars and close to animals that were reported to have been attacked by hematophagous bats (ESBÉRARD et al., 1994). In the other sites, nets were set up around fruiting trees, mainly sapucaias and fig trees (Nunes et al., 2007; Pereira \& Esbérard, 2009). Until the $50^{\text {th }}$ night, we sampled only sites in the zoo; afterwards, sampling in the zoo was interpolated with 20 nights of sampling near fruiting trees.

In addition to mist netting, roosts were sampled (38 times) and in eight occasions we received bats found by park visitors or city employees, who worked in the maintenance and pruning of the trees or in the cleaning of the park. Roosts were identified based on information given by gardeners, street-sweepers, and other park employees, or by finding feces or fruit remains near the sampling sites. We investigated human constructions (bridges, manholes, disused rooms, cellars, and roofs - see EsBÉRARD et al., 1999), hollow trees, rock crevices, palm canopies (Simmons \& Voss, 1998), and the artificial cave. After locating each roost, bats were captured preferably during the day by hand, with long tweezers covered with foam on the extremities, entomological hand nets or traps (EsBÉRARD, 2003b). When capturing was not possible with these methods, we used fishing nets (mesh $1 \frac{1 / 2 ")}{}$ ) or mist nets set up at the access to the roost, in order to capture bats while leaving the roost. These working hours and number of nets were not considered in the total sampling effort.

The captured animals were marked with holes in the dactylopatagium (punch-marking - BonaCCORSO \& Smythe, 1972) until 1992, with a tattoo plier until 1995, or with plastic necklaces with colored cylinders (ESBÉRARD \& DAEMON, 1999) from 1996 on. Recaptures were not included in estimates of diversity, expected number of species, and capture efficiency. Vouchers were obtained by killing one or more specimens of each species (VIzotTo \& TADDEI, 1973), and deposited in the reference collection of the Laboratory of Bat Diversity (Laboratório de Diversiade de Morcegos - LADIM) (Process 1755/89 - IBAMA/ SUPES/RJ), located at Universidade Federal Rural do Rio de Janeiro. The captured bats were identified in the field using keys (mainly Vizotto \& TAdDeI, 1973; MarquesAguiar, 1994; Emmons \& Feer, 1997; Gregorin \& Taddei, 2002). The nomenclature followed Simmons (2005), but Artibeus planirostris (Spix, 1823) was considered as a valid species in the study region.

The expected number of species and the completeness of richness estimates were calculated using the Chao-BC estimator in the program Spade (Снао \& SHEN, 2009). Species accumulation curves were built using as sampling units nights, roosts and individuals. Curves based on captures were built through randomization $(1,000$ iterations) in the program Ecosim 7.0.

The samples are separated into two groups: (1) with mist nets opened far from fruiting Ficus tree and other fruit trees (more than $30 \mathrm{~m}$ ) and (2) with mist nets opened near Fig trees, enclosing each tree in a circle 5-10 $\mathrm{m}$ of the trunk. Separate accumulation curves were built and compared using data from captures near fig trees and far from them; separate species rankings were also built and compared. Rarefaction was calculated separately for data from captures in roosts, in nets close to fig trees, and in nets far from fig trees in the program Past, in order to compare species richness among these groups. Diversity was estimated using the Rényi series (MeLo, 2008) and compared between captures made close to fig trees and far from fig trees. Movements of recaptured bats in QBV were assessed in terms of linear distance, origin and destination.

\section{RESULTS}

We analyzed 3,256 captures, including 133 recaptures, out of which 2,928 were obtained in mist nets and 187 inside roosts; eight specimens were received from park visitors or gardeners. Twenty-one bat species were confirmed in QBV (Tab. I): 19 captured in mist nets, 14 in day roosts, one in a night roost, and two found by park visitors or gardeners. The capture efficiency in mist nets was 28.15 captures/night, 3.69 captures/h, 0.61 captures/ net-h, and 0.04 captures $/ \mathrm{m}^{2} . h$.

The dominant species was Artibeus lituratus (Olfers, 1818), which represented $38.02 \%$ of all captures and was present in $91.35 \%$ of the sampling nights, followed by Artibeus fimbriatus Gray, 1838 with $29.18 \%$ of all captures and present in $88.46 \%$ of the sampling nights. Desmodus rotundus (E. Geoffroy, 1810) was present in $26.92 \%$ of the sampling nights and was captured only in the zoo. The other species with at least five captures were found both in the park and in the zoo.

Thirty roosts were sampled (Tab. II); 10 in hollow trees, with confirmed use by Noctilio leporinus (Linnaeus, 1758), A. fimbriatus, Sturnira lilium (E. Geoffroy, 1810), Cynomops abrasus (Temmink, 1827), and Molossus molossus (Pallas, 1766) (Tab. II). The tree species in which roosts were found were sibipiruna (Caesalpinia 
Tab. I. Species captured in mist nets, roosts and received through donations, and the total of recaptures in Quinta da Boa Vista, Rio de Janeiro, Brazil, from 1989 to 2004 (F, in nets set up near fruiting fig trees).

\begin{tabular}{|c|c|c|c|c|c|}
\hline Species & Captures & $\begin{array}{l}\text { Nets } \\
\text { Total/F }\end{array}$ & Roosts & Donations & Recaptures \\
\hline \multicolumn{6}{|l|}{ Family Noctilionidae } \\
\hline Noctilio leporinus (Linnaeus, 1758) & 37 & $4 / 0$ & 33 & 0 & 0 \\
\hline \multicolumn{6}{|l|}{ Family Phyllostomidae } \\
\hline Phyllostomus hastatus (Pallas, 1767) & 37 & $36 / 17$ & 1 & 0 & 0 \\
\hline Glossophaga soricina (Pallas, 1766) & 47 & $35 / 2$ & 11 & 0 & 1 \\
\hline Carollia perspicillata (Linnaeus, 1758) & 7 & $6 / 1$ & 1 & 0 & 0 \\
\hline Artibeus fimbriatus Gray, 1838 & 997 & $939 / 275$ & 11 & 0 & 47 \\
\hline Artibeus planirostris (Spix, 1823) & 165 & $155 / 80$ & 2 & 1 & 7 \\
\hline Artibeus obscurus (Schinz, 1821) & 23 & $22 / 9$ & 0 & 0 & 1 \\
\hline Artibeus lituratus (Olfers, 1818) & 1,299 & $1,255 / 427$ & 16 & 5 & 23 \\
\hline Chiroderma doriae Thomas, 1891 & 3 & $3 / 0$ & 0 & 0 & 0 \\
\hline Chiroderma villosum Peters, 1860 & 1 & $1 / 1$ & 0 & 0 & 0 \\
\hline Sturnira lilium (E. Geoffroy, 1810) & 178 & $157 / 15$ & 9 & 2 & 10 \\
\hline Desmodus rotundus (E. Geoffroy, 1810) & 52 & $49 / 0$ & 0 & 0 & 3 \\
\hline Platyrrhinus lineatus (E. Geoffroy, 1810) & 180 & $173 / 70$ & 1 & 0 & 6 \\
\hline Platyrrhinus recifinus (Thomas, 1901) & 5 & $5 / 5$ & 0 & 0 & 0 \\
\hline \multicolumn{6}{|l|}{ Family Vespertilionidae } \\
\hline Myotis nigricans (Schinz, 1821) & 35 & $33 / 11$ & 2 & 0 & 0 \\
\hline Myotis cf. riparius Handley, 1960 & 9 & $8 / 3$ & 0 & 0 & 1 \\
\hline Lasiurus ega (Gervais, 1856) & 8 & $1 / 0$ & 7 & 0 & 0 \\
\hline Lasiurus blosevillii (Lesson \& Garnot, 1826) & 1 & $1 / 0$ & 0 & 0 & 0 \\
\hline \multicolumn{6}{|l|}{ Family Molossidae } \\
\hline Molossus molossus (Pallas, 1766) & 157 & $45 / 11$ & 78 & 0 & 34 \\
\hline Cynomops abrasus (Temmink, 1827) & 14 & $0 / 0$ & 14 & 0 & 0 \\
\hline \multirow[t]{2}{*}{ Nyctinomops macrotis (Gray, 1840) } & 1 & $0 / 0$ & 1 & 0 & 0 \\
\hline & 3,256 & $2,928 / 927$ & 187 & 8 & 133 \\
\hline
\end{tabular}

Tab. II. Roosts found in Quinta da Boa Vista, Rio de Janeiro, Brazil from 1989 to 2004.

\begin{tabular}{|c|c|c|}
\hline Bat species & Roost type/description & $\begin{array}{l}\text { Number of } \\
\text { roosts }\end{array}$ \\
\hline Noctilio leporinus & Hollow palm tree at $15 \mathrm{~m}$ above ground & 1 \\
\hline Phyllostomus hastatus & Tree hollow at $2 \mathrm{~m}$ above ground & 1 \\
\hline \multirow{2}{*}{ Glossophaga soricina } & Abandoned room & 1 \\
\hline & Artificial cave & 1 \\
\hline Artibeus fimbriatus & Hollow trees, height -2 and $3 \mathrm{~m}$, and artificial cave & 2 \\
\hline Artibeus lituratus & Palm tree leaves, from 1 to $15 \mathrm{~m}$ above ground & 5 \\
\hline Artibeus planirostris & Artificial cave & 1 \\
\hline Sturnira lilium & Tree hollow with access at ground level, but bats roosted at over $3 \mathrm{~m}$ above ground & 1 \\
\hline Platyrrhinus lineatus & Palm tree leaves, from 2 to $4 \mathrm{~m}$ above ground & 4 \\
\hline Myotis nigricans & Artificial cave & 1 \\
\hline Lasiurus ega & $\begin{array}{l}\text { Among dead leaves of palm trees ( } 5 \text { isolated individuals) from } 2 \text { to } 4 \mathrm{~m} \text { above } \\
\text { ground and inside the artificial cave }\end{array}$ & 5 \\
\hline Molossus molossus & Hollow trees from 2 to $4.5 \mathrm{~m}$ above ground & 5 \\
\hline Cynomops abrasus & $\begin{array}{l}\text { Hollow tree at } 6 \mathrm{~m} \text { above ground and one individual in the roof lining of a } \\
\text { residence }\end{array}$ & 1 \\
\hline Nyctinomops macrotis & Crevice in a stone wall & 1 \\
\hline & & 30 \\
\hline
\end{tabular}

Tab. III. Sampling sites, total of captures, species richness, estimated species richness, sample completeness, and exclusive species (N, sampling events in roosts or sampling nights, ${ }^{\text {a }}$, number of roosts inspected).

\begin{tabular}{|c|c|c|c|c|c|c|}
\hline Sampling & $\mathrm{N}$ & Captures & Richness & Estimate & $\begin{array}{c}\text { Completeness } \\
(\%)\end{array}$ & $\begin{array}{c}\text { Exclusive } \\
\text { species }\end{array}$ \\
\hline Roosts & $38(31)^{\mathrm{a}}$ & 187 & 14 & $18.0 \pm 5.3$ & 77.78 & $\begin{array}{l}\text { C. abrasus } \\
\text { N. macrotis }\end{array}$ \\
\hline Nets & 104 & 3,102 & 19 & $22.0 \pm 4.5$ & 86.36 & $\begin{array}{l}\text { A. obscurus } \\
\text { D. rotundus } \\
\text { M. riparius } \\
\text { L. blosevilli }\end{array}$ \\
\hline Fig trees & 20 & 927 & 14 & $16.0 \pm 3.7$ & 87.50 & $\begin{array}{l}\text { C. villosum } \\
\text { P. recifinus }\end{array}$ \\
\hline Without fig trees & 84 & 2,055 & 16 & $16.0 \pm 0.5$ & 100 & C. doriae \\
\hline Total & 142 & 3,282 & 21 & $24.0 \pm 4.6$ & 87.50 & \\
\hline
\end{tabular}


peltophoroides), mango tree (Mangifera indica), money tree (Pachira aquatica), fig tree (Ficus religiosa), flamboyant (Delonix regia), silk floss tree (Chorisia speciosa), angicobranco (Anadenanthera colubrina), and royal palm (Roystonea regia). Fifteen roosts were found in palm trees, one in a hollow tree, five among dead leaves and the others in the underside of green leaves. Most roosts were located high, at 1 to $15 \mathrm{~m}$ above ground. Only two species were captured in roosts and not sampled with mist nets: C. abrasus and Nyctinomops macrotis (Gray, 1840).

On the seventh sampling night, thirteen out of the 19 species captured in mist nets had been already confirmed and the collector's curve stabilized until the $50^{\text {th }}$ sampling night $(0.26$ species/night $)$ (Fig. 3$)$. The other six species were captured between the $51^{\text {st }}$ and the $89^{\text {th }}$ sampling night ( 0.12 species/night). The last species to be captured, Platyrrhinus recifinus (Thomas, 1910) and Chiroderma villosum Peters, 1860, were sampled in the $87^{\text {th }}$ and $89^{\text {th }}$ sampling nights, in nets set up around a fruiting Ficus tomentella (Figs 3-8). The randomized species accumulation curve had a small slope $[$ Richness $=$ $2.6849 * \log$ (captures) $-3.5211, \mathrm{r}=0.85]$ (Fig. 4).

The collector's curve for 84 sampling nights far from fig trees grew slow after 1,100 captures, with the addition of three species, reaching 16 species in total [Richness $=$ $1.9837 * \log ($ captures $)+0.5113$ ] (Fig. 6). The curve for 20 sampling nights near fig trees grew fast until 500 captures, reaching 14 species, and no more species were added $[$ Richness $=2.3103 * \log ($ Captures $)-1.0957]$ (Fig. 6). The six species of non-frugivorous bats captured near fig trees [M. molossus, Myotis nigricans (Schinz, 1821), Myotis riparius Handley, 1960, Phyllostomus hastatus (Pallas, 1767), Lasiurus blosevillii (Lesson \& Garnot, 1826) and Lasiurus ega (Gervais, 1856)] were added until the sixth sampling night, and the last three species were frugivorous (C. villosum, P. recifinus e Carollia perspicillata (Linnaeus, 1758)]. Two species were captured only near fig trees $(C$. villosum and $P$. recifinus), and only one frugivorous species was not captured near fig trees (Chiroderma doriae Thomas, 1891). In samples far from fig trees, eight frugivorous species [A. lituratus, A. fimbriatus, Artibeus obscurus (Schinz, 1821), A. planirostris, C. perspicillata, C. doriae, Platyrrhinus lineatus (E. Geoffroy, 1810 and S. lilium)] were captured between the $1^{\text {st }}$ and the $6^{\text {th }}$ sampling nights (average 2.71 nights), and the last species captured were $N$. leporinus, M. riparius and L. ega.

The number of expected species for this park was $24.0 \pm 4.6$ (Tab. III), and the total sampled represented $87.5 \%$ of the expected. The number of expected species considering only roosts was $18.0 \pm 5.3$ (Tab. III), so sampling in roosts was $77.78 \%$ complete. The species accumulation curve did not stabilize (Fig. 5). The number of species, pooling captures in nets near and far from fig trees, was over $85 \%$ of the expected (Tab. III); eight frugivorous species were captured in nets near fig trees, and nine were captured in nets far from fig trees. The samples from nets close to fig trees and far from them did not differ in terms of the two most frequent species: A. lituratus and A. fimbriatus (Figs 7, 8). The rarefaction curves show that higher richness is expected for captures in roosts (Fig. 9). Captures in nets near fig trees had lower richness than captures far from fig trees (Fig. 9). Diversity was similar between samples near fig trees and far from them (Fig. 10).

Six movements of 13 bats of three species were observed in this study (Fig. 11). Three came from QBV and had as destination other sites in the urban area. One specimen of A. fimbriatus marked in QBV was found in a backyard in a moderately urbanized area (houses with backyards, $6.0 \mathrm{~km}$ away); other four A. fimbriatus marked in QBV were recaptured in the campus of the Oswaldo Cruz Foundation (6.0 km away); and one specimen of $A$. lituratus marked in QBV was recaptured in Campo de Santana, another park (4.8 km away) located in a highly urbanized area. The three movements originated in other sites, which had QBV as destination, came from reserves, two with secondary Atlantic Forest and one with restinga vegetation. In $\mathrm{QBV}$, two specimens of $A$. lituratus and three of $A$. fimbriatus were recaptured, which were ringed by M. R. Nogueira (UFRRJ) in the Botanical Gardens of Rio de Janeiro (7.5 km away); there were also one $D$. rotundus, marked by one of the authors (C. E. L. Esbérard) in Grajaú State Park (4.5 km away), and one A. fimbriatus marked by B. Costa (UFRRJ) in the park Bosque da Barra (27 km away).

\section{DISCUSSION}

Twenty-one bat species in an urban park within a metropolis is a remarkable richness. However, even with a high mist netting effort it was not possible to reach the expected richness. In addition to the species analyzed in the present study there is also one specimen of Nyctynomops laticaudatus (E. Geoffroiy, 1850) captured in QBV and deposited in the Museu Nacional (MN6513, captured in 22 February 1943). Green areas in urbanized regions of Brazil exhibit richness varying from 16 (Belo Horizonte) to 25 species (Londrina and São Paulo) (LimA, 2008). Previous studies carried out in urban environments showed that urbanization results in a decrease in bat diversity (KURTA \& Teramino, 1992; Rydell et al., 1994; Ávila-Flores \& FENTON, 2005). However, several local conditions can lead to high species richness, such as the presence of water, the connectivity among green areas through tree corridors, and the high availability of roosts and food (e.g., McKinNEY, 2002).

Among the species captured in QBV, there are species usually considered as abundant in the Neotropics, which have broad geographic distribution, including $P$. hastatus, Glossophaga soricina (Pallas, 1766), C. perspicillata, S. lilium, Artibeus spp., D. rotundus, M. nigricans, and $M$. molossus (e.g., Peracchi \& Albuquerque, 1971, 1986; Jones, 1976; Pedro et al., 1995; Reis \& Müller, 1995; Bredt \& UiedA, 1996; Silva et al., 1996). Most of these 

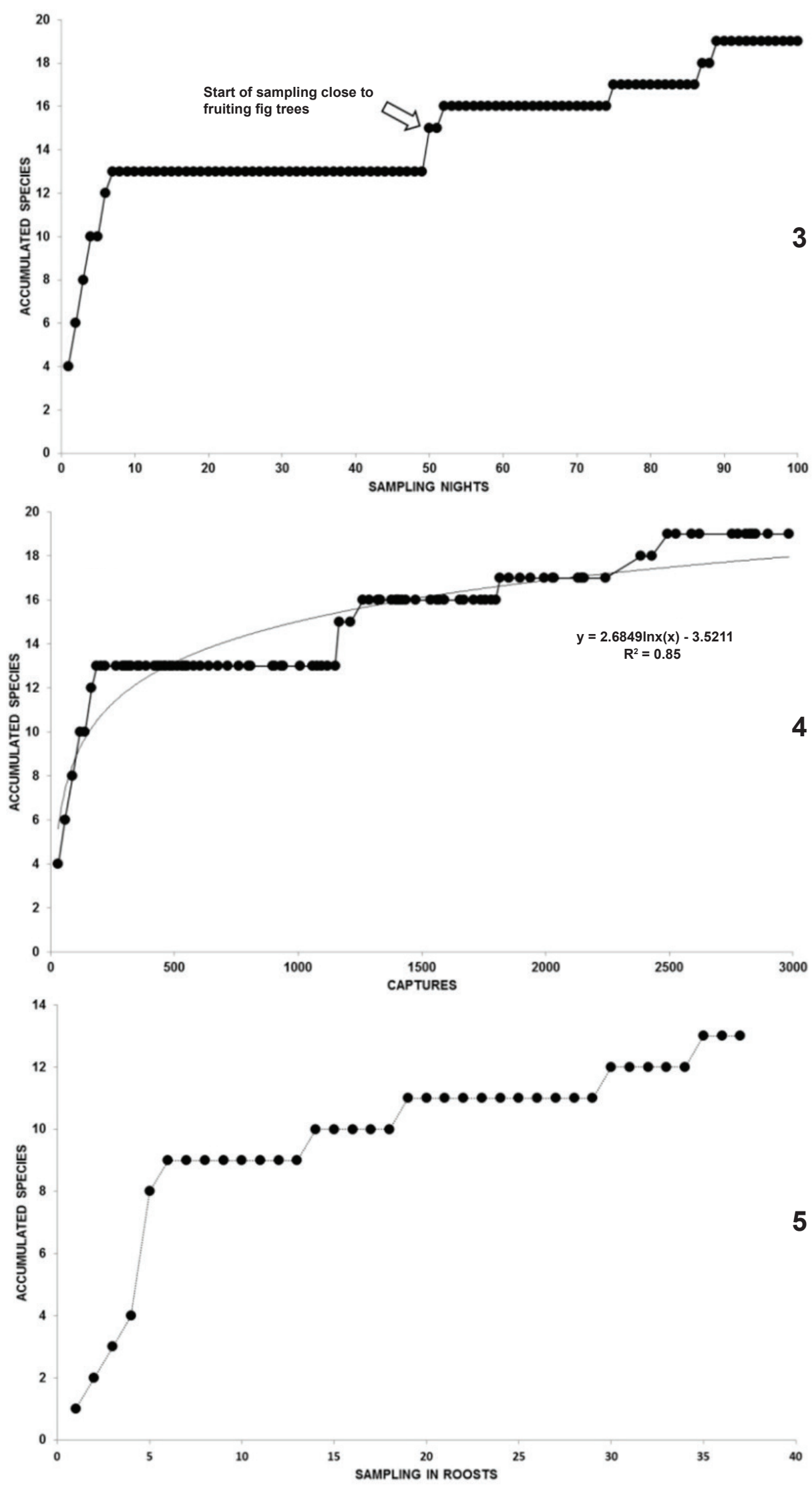

Figs 3-5: 3, Collector's curve for Quinta da Boa Vista from 1989 to 2004 based on sampling nights; 4, species accumulation curve and randomized species accumulation curve (line) based on specimens captured; 5 , species accumulation curve for the 38 sampling events in day roosts. 


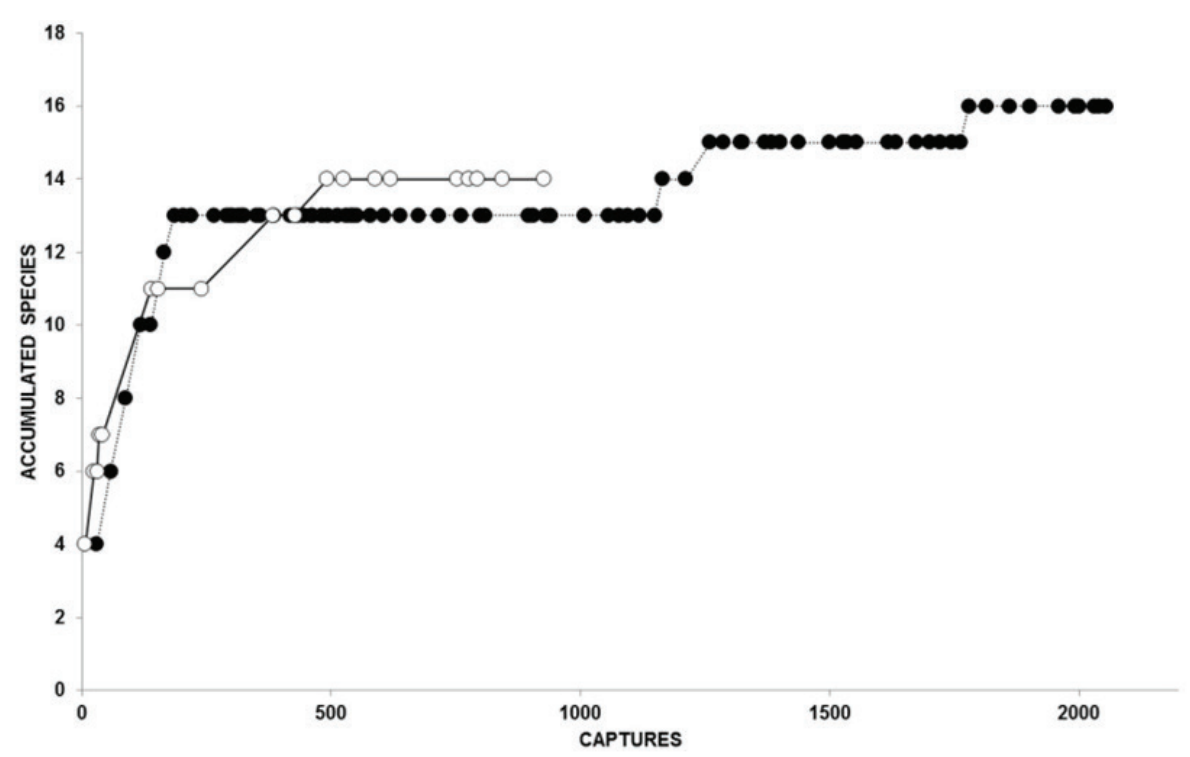

Fig. 6. Species accumulation curve for sampling near fig trees (white circles) and far from fig trees (black circles).

species occur in all Americas (see Simmons, 2005).

In QBV six insectivorous species were captured. A higher abundance and richness of insectivorous bats can be found in roosts; studies in urban areas in Brazil report more insectivorous species than in forests (e.g., SiLva et al., 1996). Sampling in roosts reached $77 \%$ of expected number of species, whereas the total sample and samples near and far from fig trees surpassed $85 \%$ of the expected number of species. In order to reach the goal of $85 \%$ of the expected number of species in roosts (SAMPAIO et al., 2003), a higher effort would be needed, and probably more species of Molossidae and Vespertilonidae would be sampled.

The high number of roosts found in palm trees and tree hollows in QBV suggests that bats can find high availability of these roosts in urban areas. The availability of hollow trees and other roosts is an important factor that should be considered in the analysis of bat occurrence (e.g., Humphrey, 1975; Kunz, 1982; Brigham et al., 1997; JOHNSON et al., 2008). Bats may show fidelity to roosts in hollow trees (e.g., LewIs, 1995), but there are species that periodically change roosts and so need a high availability of them (e.g., YAsur et al., 2004). Hollows are more frequent in trees that undergo pruning or breakage of branches (Milano \& Dalcin, 2000) or in trees that are old (Lewis, 1995; Brigham et al., 1997; YASUI et al., 2004), such as many trees in our study site and on streets of Rio de Janeiro. In Brazil, mainly Molossidae and Vespertilionidae bats do frequently use roof lining and other structures in residences as roosts in urban areas (BREDT \& UIEDA, 1996; EsBÉRARD et al., 1999; Lima, 2008), but we still need to investigate the availability of hollow trees and their occupancy rates by these bats (YASUI et al., 2004). A study carried out in a roof lining and in a hollow tree, where colonies of Molossus rufus E. Geoffroy, 1805 roosted, showed that bats use these sites during the whole year, but each individual uses them for short periods, suggesting that the animals change roosts periodically (ESBÉRARD, 2002).

Artibeus lituratus is the predominant species in urban areas of Brazil (BARros et al., 2006; Lima, 2008; Oprea et al., 2009; Gazarini \& Pedro, 2013). This predominance evidences the high plasticity of this species (SAzIMA et al., 1994), which benefits from urban forestry (BREDT \& UiEDA, 1996). Landscape architects of large cities use fast-growing tree species and prefer exotic species (SANTOS et al., 2009). Species such as the sea almond (Terminalia cattapa, family Combretaceae) are typical; it is found in several cities and provides food for Artibeus bats all year long (Galetti \& Morelato, 1994; Sazima et al., 1994).

In QBV, C. perspicillata represented only $0.20 \%$ of the captures. This is totally different from what has been reported for forests in the state of Rio de Janeiro, where this species predominates (see Baptista \& Mello, 2001; Esbérard et al., 2006; Dias \& Peracchi, 2008; Esbérard \& Bergallo, 2008; Esbérard, 2009), or at least occurs at high density (e.g., EsBÉRARD, 2003a). Similar results were obtained by ReIs \& MULLER (1995), who sampled the university campus and the urban area of Londrina, southern Brazil, and found a low capture rate for this species in city. This species adapts well to disturbed environments because they consume fruits of pioneer plant species present in the understory (FARIA, 2006), but absent in urban areas.

Desmodus rotundus was only collected in nets set up close to zoo animals. However, its capture could be expected in other areas of QBV, since this species is common in the city of Rio de Janeiro, where it attacks pets and even humans (EsBÉrARD et al., 1998 and 2001). No roost of this species was located in the study area, but a male specimen, which had been previously marked in Grajaú State Park in Maciço da Tijuca, was captured; it moved over a very large and highly urbanized area. This species of hematophagous bat has been found in other Brazilian urban areas, where it preys on domestic dogs (EsBÉRARD et al., 2001; UiEDA, 1995; CARNEIRO et al., 2005; 

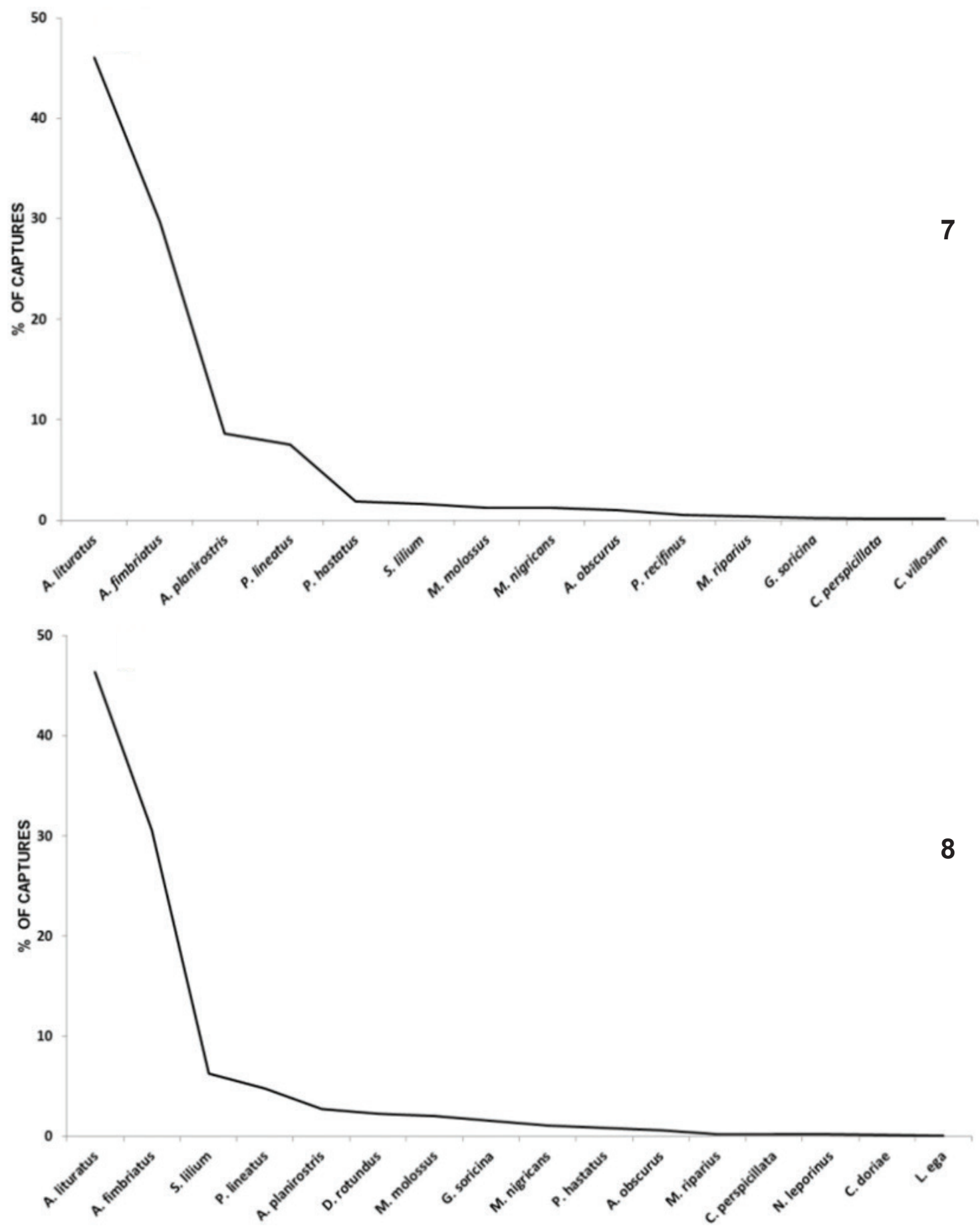

Figs 7-8: 7, abundance rankings for sampling carried out near fig trees; 8, and far from fig trees.

FERRAz et al., 2007).

In Brazil there are so far no long-term surveys in urban parks that allow detailed comparisons of richness and abundance, but the capture efficiency observed in QBV can be considered as high compared with surrounding forest areas (0.04 bats/h-net - see EsBÉRARD, 2003a). Sampling nights close to fig trees resulted in very high efficiency in QBV, surpassing 1.0 bats/h-net (NunEs et al., 2007; PEREIRA \& EsBÉRARD, 2009).

Fruit tree species, mainly of Ficus, are an important food source for frugivorous bats (MORRISON, 1980; KALKO et al., 1996), and the fig trees of QBV represent a constant source of nutrients. In QBV there are more than 35 adult fig trees. In a small forest fragment in Campinas, FigueIREDO (1996) found 11 fig trees that produced figs during the whole year. However, the high density of fig trees in QBV did not result in high richness of frugivorous bats. Sampling near fruiting fig trees did not result in higher richness than sampling far from these trees or out of the fruiting period, as already observed in forest areas (KALKO et al., 1996). 

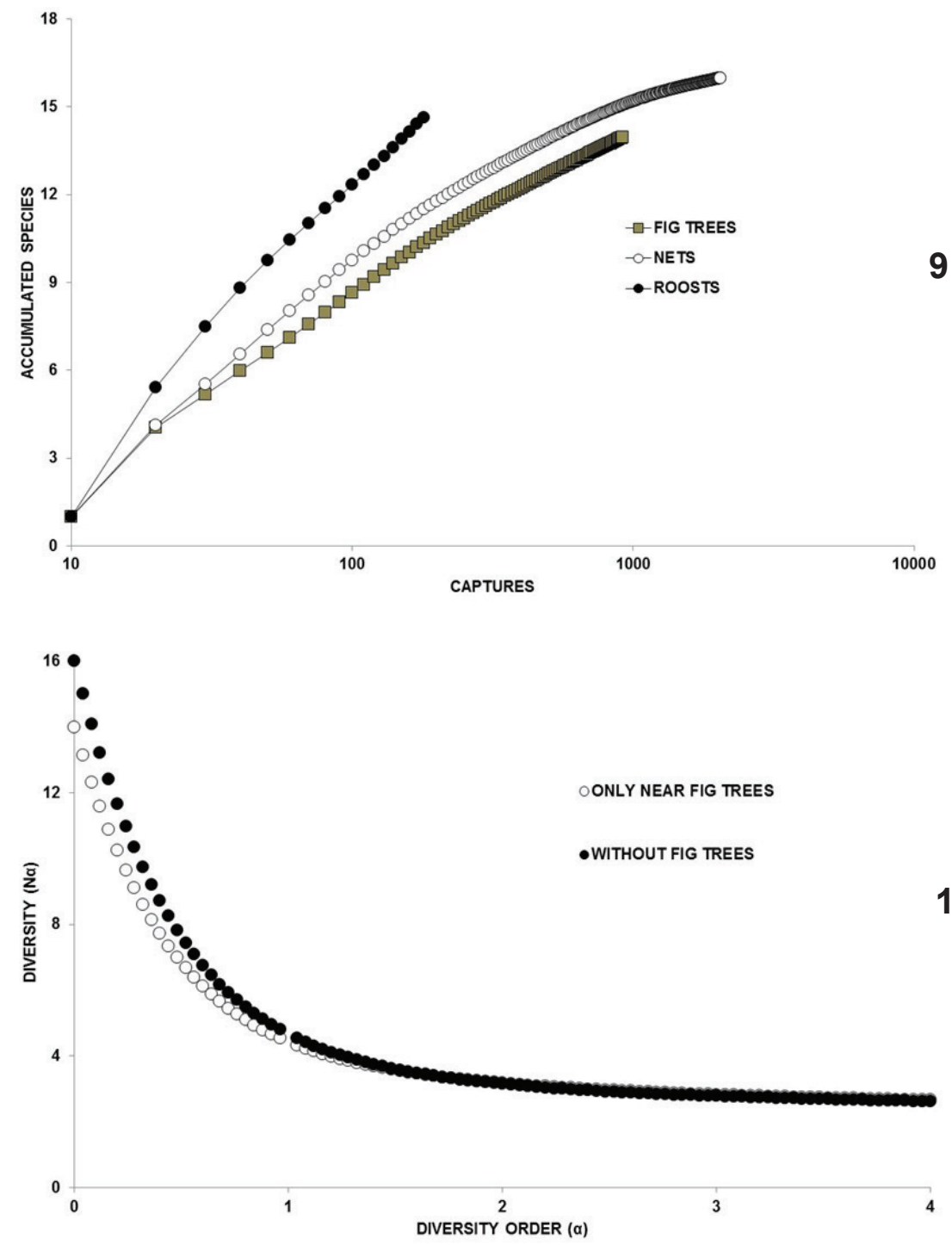

Figs 9, 10: 9, Rarefaction for captures in roosts, in nets far from fruiting fig trees, and in nets near fruiting fig trees; 10, Rényi series for diversity comparison between sampling with nets far from fruiting fig trees and near fruiting fig trees.

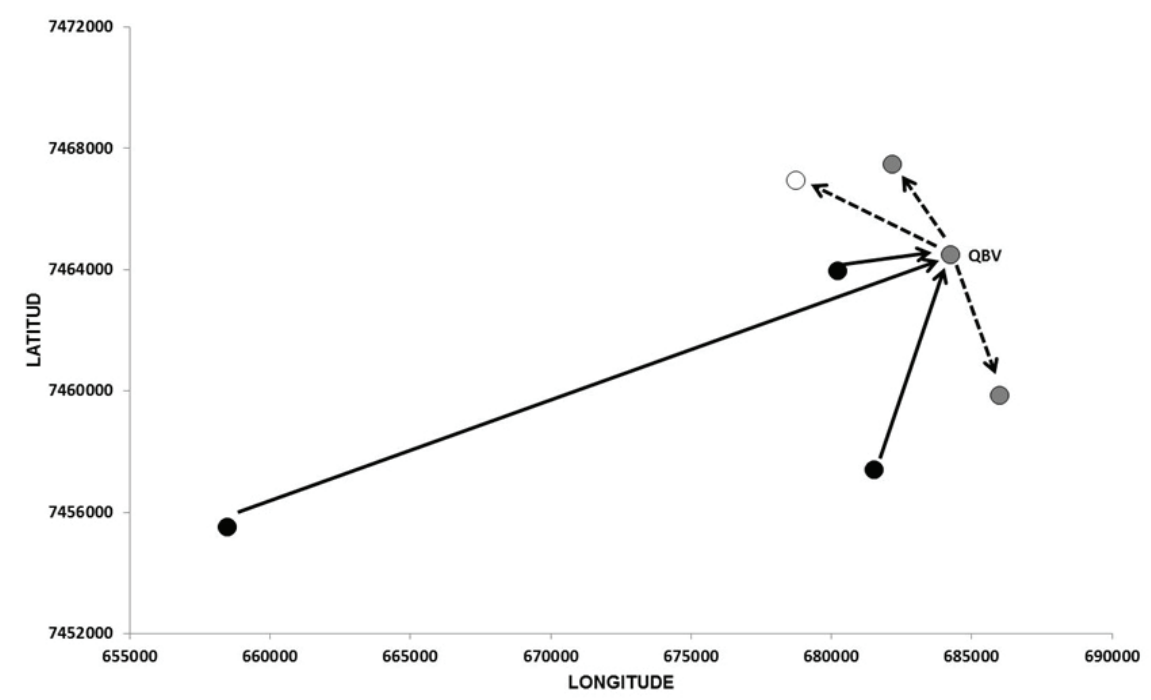

Fig. 11. Movements of bats marked or recaptured in Quinta da Boa Vista. Black dots represent reserves, grey dots represent urban parks, and the white dot represents the residential area. Arrows represent the direction of each movement. 
Therefore, a high density of frugivores may be maintained in urban areas, but species that depend on forests do not enter urban areas, and are not attracted by urban fruiting fig trees.

The recapture of bats marked in surrounding forest fragments and in QBV shows the importance of urban parks for the maintenance of bat diversity (ÁvILA-FLoRES \& Fenton, 2005; Oprea et al., 2009). Such movements show that A. lituratus A. fimbriatus, and D. rotundus use QBV (and probably other parks) to survive in urban areas. Considering movement distances already recorded for Artibeus bats in southeastern Brazil, which can be larger than $30 \mathrm{~km}$ (COSTA et al., 2006; MENEZES-JÚNIOR et al., 2008; Mendes et al., 2009), we may suppose that $A$. fimbriatus and $A$. lituratus move around the whole urban area and surroundings, flying between all urban parks and remaining forest areas, and feeding on trees (see EsTRADA \& Coates-Estrada, 2001; Oprea et al., 2009).

Acknowledgements: Márcia Baptista and João Alves provided data on bats captured in QBV and deposited in the Museu Nacional (UFRJ); the Fundação RIOZOO, the management of Quinta da Boa Vista and the management of the Museu Nacional allowed sampling. The Parks and Gardens Foundation and the City Company of Urban Waste (COMLURB) provided us with information on roosts and rescued some bats during the cleaning and maintenance of trees. A. Chagas, A. G. Motta, A. P. Cifali, M. Baptista, E. M. Luz, and A. Bezerra helped us in the field. Dr. D. Dias (Fiocruz) confirmed the identification of some vouchers; Dr. C. E. L. Esbérard a research productivity fellowship (process 151029/2004-0). FAPERJ granted C.E.L. Esbérard a 'Jovem Cientista do Nosso Estado' fellowship (process E-26/102.201/2009). Dr. H. G. Bergallo thanks FAPERJ (process E-26/103.016/2011), CNPq (process 307715/2009-4) and Prociência/UERJ for the researcher grants. This study was carried out under special collecting permits (Process 1785/89-IBAMA and SISBIO 10356-1).

\section{REFERENCES}

Ávila-Flores, R. \& Fenton, M. B. 2005. Use of spatial features by foraging insectivorous bats in a large urban landscape. Journal of Mammalogy 86:1193-1204.

Baptista, M. \& Mello, M. A. R. 2001. Preliminary inventory of the bat species of the Poço das Antas Reserve, RJ. Chiroptera Neotropical 7(1-2):133-135.

Barros, R. S. M.; Bisaggio, E. L. \& Borges, R. C. 2006. Morcegos (Mammalia, Chiroptera) em fragmentos florestais urbanos no município de Juiz de Fora, Minas Gerais, sudeste do Brasil. Biota Neotropical 6(1). Available at $<\mathrm{http}$ ://www.biotaneotropica.org. $\mathrm{br} / \mathrm{v} 6 \mathrm{n} 1 / \mathrm{pt} / \mathrm{abstract}$ ?inventory+bn02206012006>. Accessed on 08 June 2012

Bergallo, H. G.; Fidalgo, E. C. C.; Rocha, C. F. D.; Uzeda, M. C.; Costa, M. B.; Alves, M. A. S.; Van Sluys, M.; Santos, M.; Costa, T. C. C. \& Cozzolino, A. C. R. 2009. Estratégias e ações para a conservação da biodiversidade no Estado do Rio de Janeiro. Rio de Janeiro, Instituto Biomas. 344p.

Bonaccorso, F. J. \& Smythe, N. 1972. Punch-Marking Bats: An Alternative to Banding. Journal of Mammalogy 53:389-390.

Bredt, A.; AraúJo, F. A. A.; CaEtano-Júnior, J.; Rodrigues, M. G. R.; Yoshizana, M.; Silva, M. M. S; Harmani, N. M. S; Massunaga, P. N. T.; BÜRER, S. P.; Porto, V. A. R. \& UiedA, W. 1996. Morcegos em áreas urbanas e rurais: manual de manejo e controle. Brasília, Fundação Nacional de Saúde. 116p.

BREDT, A. \& UieDA, W. 1996. Bats from urban and rural environments of the Distrito Federal, mid-western Brazil. Chiroptera Neotropical 2(2):54-57.

Brigham, R. M. R.; Grindal, S. D.; Firman, M. C. \& Morissette, J.
L. 1997. The influence of structural clutter on activity patterns of insectivorous bats. Canadian Journal of Zoology 75:131-136.

Carneiro, R. L.; Martins, M. S.; Brasil, T. K.; Silva, L. L. A.; Santos, E. F. \& Souza L. E. B. 2005. Análise das agressões em humanos por morcegos hematófagos ocorridas em três municípios baianos no período de 1986 a 1995. Revista Brasileira de Saúde Pública e Produção Animal 6(1):1-7.

Chao, A. \& Shen, T. J. 2009. SPADE (Species Prediction and Diversity Estimation). Available at $<\mathrm{http}: / /$ chao.stat.nthu.edu.tw/softwareCE. html $>$. Accessed on 05 October 2012.

CôRTes, V. A.; SouzA, L. C.; UiedA, W. \& Figueiredo, A. C. 1994. Abrigos diurnos e infecção rábica em morcegos de Botucatu, São Paulo, Brasil. Veterinária e Zootecnia 6:179-186.

Costa, L. M.; Prata, A. F. D.; Moraes, D.; Conde, C. F. V.; JordãoNogueira, T. \& Esbérard, C. E. L. 2006. Deslocamento de Artibeus fimbriatus sobre o mar. Chiroptera Neotropical 12(2):289-290.

Dias, D. \& Peracchi, A. L. 2008. Quirópteros da Reserva Biológica do Tinguá, estado do Rio de Janeiro, sudeste do Brasil (Mammalia: Chiroptera). Revista Brasileira de Zoologia 25:333-369.

Emmons, L. H. \& Feer, F. 1997. Neotropical rainforest mammals: a Field Guide. 2ed. Chicago, University of Chicago Press. 380p.

EsBÉRARD, C. E. L. 1999. Observações sobre o ataque de morcegos hematófagos a cães. Revista Brasileira de Medicina Veterinária 21(5):219-220

2002. Composição e reprodução de Molossus rufus (E. Geoffroy) (Chiroptera: Phyllostomidae) em um refúgio no sudeste do Brasil. Revista Brasileira de Zoologia 19(4):1153-1160.

.2003a. Diversidade de morcegos em uma área de Mata Atlântica regenerada no sudeste do Brasil (Mammalia: Chiroptera). Revista Brasileira de Zoociências 5(2):189-204.

2003b. Armadilha para retirada de morcegos abrigados em telhado. Chiroptera Neotropical 9(1-2):164-166.

2007. Influência do Ciclo Lunar na Captura de Morcegos Phyllostomidae. Iheringia, Série Zoologia 97:81-85.

2009. Capture sequence and relative abundance of bats during surveys. Revista Brasileira de Zoologia 26(1):103-108.

Esbérard, C. E. L. \& Bergallo, H. G. 2008. Influência do esforço amostral na riqueza de espécies de morcegos no sudeste do Brasil. Revista Brasileira de Zoologia 25(1):67-73.

Esbérard, C. E. L.; Cifali, A. P. \& Thebbas, F. 2001. Ação de morcegos hematófagos no Município do Rio de Janeiro. Revista Brasileira de Medicina Veterinária 23(5):219-220.

Esbérard, C. E. L.; Chagas, A. S. \& Luz, E. M. 1999. Uso de residências por morcegos no Estado do Rio de Janeiro (Mammalia: Chiroptera). Revista Brasileira de Medicina Veterinária 21(1):17-20.

Esbérard, C. E. L.; Chagas, A. S.; LuZ, E. M.; Carneiro, R. A. \& Martins, L. F. 1998. Considerações sobre o morcego hematófago (Desmodus rotundus) na cidade do Rio de Janeiro, RJ, Brasil. Revista Brasileira de Medicina Veterinária 19(5):209-215.

EsbérARD, C. E. L. \& DAEMON, C. 1999. Novo método para marcação de morcegos. Chiroptera Neotropical 5(1-2):116-117.

Esbérard, C. E. L.; Nogueira, M. R.; Mocelin, M. A. O.; Santana, A. M. C. \& PoL, A. 1994. Análise preliminar dos problemas com morcegos no Município do Rio de Janeiro (RJ, Brasil). Anais do I Encontro Brasileiro de Ciências Ambientais 1:348-362.

Esbérard, C. E. L.; Jordão-Nogueira, T.; Luz, J. L.; Melo, G. G. S.; Mangolin, R.; JucÁ, N., Raíces, D. S. L.; Enrici, M. C. \& Bergallo, H. G. 2006. Morcegos da Ilha Grande, Angra dos Reis, RJ, Sudeste do Brasil. Revista Brasileira de Zoociências 8(2):147-153.

Estrada, A. \& Coates-Estrada, R. 2001. Species composition and reproductive phenology of bats in a tropical landscape at Los Tuxtlas, México. Journal of Tropical Ecology 17:672-646.

FARIA, D. 2006. Phyllostomid bats of fragmented landscape in the North-Eastern Atlantic Forest, Brazil. Journal of Tropical Ecology 22:531-542.

Fenton, M. B. 1997. Science and the conservation of bats. Journal of Mammalogy 78:1-15.

Ferraz, C.; AchKar, S. M. \& Kotait, I. 2007. First report of rabies in vampire bats (Desmodus rotundus) in an urban area, Ubatuba, São Paulo state, Brazil. Revista do Instituto de Medicina Tropical de São Paulo 49(6):389-390. 
Figueiredo, R. A. 1996. Vertebrates at neotropical fig species in a forest fragment. Tropical Ecology 37(1):139-141.

Fortunato, L. \& RuszczyK, A. 1997. Comunidades de lepidópteros frugívoros em áreas verdes urbanas e extra-urbanas de Uberlândia, MG. Revista Brasileira de Biologia 57(1):79-87.

Fundação SOS Mata Atlântica. 2002. Atlas da evolução dos Remanescentes Florestais da Mata Atlântica, período 1995-2000: relatório final. São Paulo, Fundação S.O.S. Mata Atlântica/INPE.

Galetti, M. \& Morellato, L. P. C. 1994. Diet of the large fruiteating bat Artibeus lituratus in a forest fragment in Brazil. Mammalia 58:661-665.

GaZArini, J. \& Pedro, W. A. 2013. Bats (Mammalia: Chiroptera) in urban fragments of Maringá, Paraná, Brazil. Check List 9(3):524-527

Gomes, M. A. S. \& SoARES, B. R. 2003. A vegetação nos centros urbanos: considerações sobre os espaços verdes em cidades médias brasileiras. Estudos Geográficos 1(1):19-29.

GREGORIN, R. \& TADDEI, V. A. 2002. Chave artificial para a identificação de Molossídeos brasileiros (Mammalia, Chiroptera). Mastozoología Neotropical 9(1):13-32.

HUMPHREY, S. R. 1975. Nursery roosts and community diversity of Nearctic bats. Journal of Mammalogy 56:321-346.

IBGE. 2010. Censo Demográfico. Available at ibge.gov.br/cidadesat/link.php?ufrj $>$. Accessed on 13 January 2012.

IPLANRIO. 1992. Anuário Estatístico da Cidade do Rio de Janeiro (1991). Rio de Janeiro, IplanRio. 312p.

Johnson, J. S.; Kiser, J. D.; Watrous, K. \& Peterson, T. S. 2008. Dayroosts of male and females eastern small-footed myotis Myotis leibii in the mid-Atlantic Ridge and valley region of West Virginia. Proceedings of the $38^{\text {th }}$ North American Bat Research Symposium. Scranton, Pennsylvania.

Jones, J. C. 1976. Economics and conservation. Special Publications, The Museum Texas Tech University 10:133-145.

Kalko, E. K. V.; Handley JR, C. O. \& Handley, D. 1996. Organization, diversity and long-term dynamics of a Neotropical bat community. In: Cody, M. L. \& SMallwood, J. A. eds. Long-term studies of vertebrate communities. San Diego, Academic Press. p.503-553.

Knegt, L. V.; Silva, J. A.; Moreira, E. C.; Sales, G. L. 2005. Morcegos capturados no município de Belo Horizonte. Arquivo Brasileiro de Medicina Veterinária e Zootecnia 57:576-583.

Kunz, T. H. 1982. Roosting ecology of bats. In: Kunz, T. H. ed. Ecology of Bats. New York, Plenum Press. p.1-55.

KuRTA, A. \& TERAmino, J. A. 1992. Bat community structure in an urban park. Ecography 15:257-261.

LEwIS, S. E. 1995. Roost fidelity of bats: a review. Journal of Mammalogy 76:481-496.

LimA, I. S. 2008. Espécies de morcegos (Mammalia, Chiroptera) registradas em parques nas áreas urbanas do Brasil e suas implicações no uso deste ambiente. In: Reis, N. R.; Peracchi, A. L. \& Santos, G. A. S. D. eds. Ecologia de morcegos. Technical Books. p.71-85.

Marques-Aguiar, S. A. 1994. A systematic review of the large species of Artibeus Leach, 1821 (Mammalia, Chiroptera) with some phylogenetic inferences. Boletim do Museu Paraense Emílio Goeldi 10:3-83.

Matarazzo-Neuberger, W. M. 1995. Comunidade de cinco parques e praças da grande São Paulo. Ararajuba 3:13-19.

MCKINNEY, M. L. 2002. Urbanization, biodiversity, and conservation. Bioscience 52:883-90.

Melo, A. S. 2008. O que ganhamos 'confundindo’ riqueza de espécies e equabilidade em um índice de diversidade? Biota Neotropical 8(3):21-27.

Mendes, P.; Vieira, T. B.; Oprea, M. \& Ditchfield, A. D. 2009. Longdistance movement of Artibeus lituratus (Chiroptera: Phyllostomidae) in the state of Espírito Santo, Brazil. Ecotropica 15:43-46.

Menezes-Jr, L. F.; Duarte, A. C.; Novaes, R. L. M.; FaÇanha, A. C.; Peracchi, A. L.; Costa, L. M.; Prata, A. F. D. \& Esbérard, C. E. L. 2008. Deslocamento de Artibeus lituratus (Olfers, 1818) (Mammalia, Chiroptera) entre ilha e continente no Estado do Rio de Janeiro,
Brasil. Biota Neotropical 8(2):243-245.

Milano, M. S. \& Dalcin, E. 2000. Arborização de vias públicas. Rio de Janeiro, Fundação Parques e Jardins, Prefeitura do Rio, Light. 206p.

MorRison, D. W. 1980. Foraging and day-roosting dynamics of canopy fruit bats in Panama. Journal of Mammalogy 61:20-29.

Nunes, M. S.; Cifali, A. P. \& Esbérard, C. E. L. 2007. Maiores figos atraem mais morcegos? Revista Brasileira de Zoociências 9(2):203-207.

Oprea, M.; Mendes, P.; Vieira, T. B. \& Ditchfield, A. D. 2009. Do wooded streets provide connectivity for bats in an urban landscape? Biodiversity and Conservation 18:2361-2371.

Pedro, W.; Geraldes, M. P.; Lopez, G. G. \& Alho, C. J. R. 1995. Fragmentação de hábitat e a estrutura de uma taxocenose de morcegos em São Paulo (Brasil). Chiroptera Neotropical 1(1):4-6.

Peracchi, A. L. \& Albuquerque, S. T. 1971. Lista provisória dos Chirópteros dos Estados do Rio de Janeiro e Guanabara (Chiroptera; Mammalia). Revista Brasileira de Biologia 31:405-413.

. 1986. Quirópteros do Estado do Rio de Janeiro, Brasil (Mammalia, Chiroptera). Publicações Avulsas do Museu Nacional 66:63-69.

Pereira, A. F. \& Esbérard, C. E. L. 2009. Captura de morcegos frugívoros junto a Ficus tomentella (Moraceae). Revista Brasileira de Zoociências 11(1): 19-23.

ReIs, N. R. \& MulLER, M. F. 1995. Bat diversity of forests and open areas in a subtropical region of south Brazil. Ecologia Austral 5:31-36.

Reis, N. R.; Lima, I. P. \& Peracchi, A. L. 2002. Morcegos (Chiroptera) da área urbana de Londrina, Paraná, Brasil. Zoologia 19(3):739-746.

Ruszczyk, A.; Rodrigues, J. J. G.; Roberts, T. M. T.; Bendati, M. M. A.; Del Pino, R. S. \& Marques, J. C. V. \& Melo, M. Q. 1987. Distribution of eight bird species in the urbanization gradient of Porto Alegre, Brazil. Ciência e Cultura 39:14-19.

Rydell, J.; Bushby, A.; Cosgrove, C.; Racey, P. A. 1994. Habitat use by bats along rivers in NE Scotland. Folha Zoologica 43:417-424

Sampaio, E. M.; Kalko, E. K. V.; Bernard, E.; Rodriguez-Herrera, B. \& HANDLEY-JR, C. O. 2003. A biodiversity assessment of bats (Chiroptera) in a tropical lowland rainforest of central Amazônia, including methodological and conservation considerations. Studies on Neotropical Fauna and Environment 38(1):17-31.

Santos, A. R.; Rocha, C. F. D. \& Bergallo, H. G. 2009. Native and exotic species in the urban landscape of the city of Rio de Janeiro, Brazil: density, richness, and arboreal deficit. Urban Ecosystems 13(2):209-222.

Sazima, I.; Fischer, W. A.; Sazima, M. \& Fisher, E. A. 1994. The fruit bat Artibeus lituratus as a forest and city dweller. Ciência e Cultura 46(3):164-167.

Silva, M. M. S.; Harmani, E. F. B.; Gonçalves, E. F. B. \& Uieda, W. 1996. Bats from the metropolitan region of São Paulo, southestern Brazil. Chiroptera Neotropical 2(1):39-41.

Simmons, N. B. 2005. Order Chiroptera. In: Wilson, D. E. \& Reeder, D. M. eds. Mammal species of the world: a taxonomic and geography ic reference. Johns Hopkins University Press. p.312-529.

Simmons, N. B. \& Voss, R. S. 1998. The mammals of Paracou, French Guiana: A Neotropical lowland rainforest fauna. Part 1: bats. Bulletin American Museum Natural History 237:1-219.

UIEDA, W. 1995. The common vampire bat in urban environments from Southeastern Brazil. Chiroptera Neotropical 1(2):22-24.

Villanueva, V. E. R. \& Silva, M. 1996. Organização trófica da avifauna do campus da Universidade Federal de Santa Catarina (UFSC), Florianópolis, SC. Biotemas 9(2):57-69.

Vizotto L. D \& TAdDei, V. A. 1973. Chave para a determinação de quirópteros brasileiros. São José do Rio Preto, Francal. 72p.

Yasui, S.; Kamijo, T.; Mikasa, A.; Shigeta, M. \& Tsuyama, I. 2004. Day roosts and roost-site selection of Ikonnikov's whiskered bat, Myotis ikonnikovi, in Nikko, Japan. Mammal Study 29(2):155-161.

Zórtea, M. \& Aguiar, L. 2001. Foraging behavior of the fishing bat Noctilio leporinus (Noctilionidae). Chiroptera Neotropical 7(12):140-14 